\title{
Unbundled institutions, human capital and growth
}

\author{
Sambit Bhattacharyya* \\ Research School of Pacific and Asian Studies (RSPAS), The Australian National University, Australia
}

\section{A R T I C L E I N F O}

\section{Article history:}

Received 20 February 2008

Revised 15 August 2008

Available online 23 August 2008

\section{JEL classification:}

011

030

043

057

Keywords:

Institutions

Human capital

Growth

\begin{abstract}
A B S T R A C T
Bhattacharyya, Sambit-Unbundled institutions, human capital and growth

We investigate the partial effects of institutions and human capital on growth. We find that cross-country regressions of the log-level of per capita GDP on instrumented measures of institutions and schooling are uninformative about the relative importance of institutions and human capital in the long run because of multicollinearity problems. Using dynamic panel regressions we show that both institutions and human capital have significant effects on growth. Using Rodrik's [Rodrik, D., 2005. Growth strategies. Handbook of Economic Growth 1 (1), 967-1014] four-way partition of institutions, we also unbundle institutions. We show that strong market creating institutions and market stabilising institutions are growth enhancing. Market regulating institutions matter up to a certain extent and market legitimising institutions does not seem to matter. Journal of Comparative Economics 37 (1) (2009) 106-120. Research School of Pacific and Asian Studies (RSPAS), The Australian National University, Australia.
\end{abstract}

(c) 2008 Association for Comparative Economic Studies. Published by Elsevier Inc. All rights reserved.

\section{Introduction}

Institutions are one of the major causes of long-run economic growth. This is documented by a growing literature on long-run economic growth (see Hall and Jones, 1999; Acemoglu et al., 2001; Rodrik et al., 2004; Easterly and Levine, 2003; and many others). ${ }^{1}$ Hall and Jones (1999) identify the effects of institutions by tracing back their origins to colonisation itself. Acemoglu et al. (2001) and Rodrik et al. (2004), on the other hand, focus on the incentives of colonial powers to build good institutions proxied by the settler mortality instrument. ${ }^{2}$ They argue that the Europeans resorted to different style of colonisation in different parts of the world depending on the feasibility of settlement. In tropical climate the mortality rate among European colonisers were extremely high which prevented them from settling there and they erected extractive institutions. Whereas, in temperate climate the mortality rate among the colonisers were low which made them ideal for settlement and they erected strong institutions in these settlements. These institutions persisted over time and they continue to influence the economic performance of these countries even long after independence. Easterly and Levine (2003), on the other hand, identify the effects of institutions by using natural resource endowments as an instrument.

\footnotetext{
* Address for correspondence: Arndt-Corden Division of Economics, Research School of Pacific and Asian Studies (RSPAS), The Australian National University, Room 7128, HC Coombs Building, Canberra ACT 0200, Australia. Fax: +61 261250443.

E-mail address: sambit.bhattacharyya@anu.edu.au.

1 Knack and Keefer (1995) also estimate the contribution of institutions to growth. Their focus however is on growth over the period 1974 to 1989.

2 We are aware of the controversy regarding the settler mortality instrument. Albouy (2008) identify several problems with the original variable in Acemoglu et al. (2001) and the revised dataset published as MIT mimeo by the same authors in March 2005 and September 2006 . We use this variable to facilitate comparison as all the papers that we analyse in Section 2 use this variable.
} 
In a recent study Acemoglu and Johnson (2005) evaluate the relative importance of 'property rights institutions' and 'contracting institutions' in the long run using a cross-sectional framework similar to the papers noted above. They show that 'property rights institutions' have a first-order effect on long-run growth and 'contracting institutions' does not seem to matter.

The literature on long-run growth noted above however is criticised by Dollar and Kraay (2003) and Glaeser et al. (2004). Dollar and Kraay (2003) document that the cross-sectional evidence is not very informative about the relative importance of trade and institutions in the long run. They show that the instruments for trade and institutions suggested by the literature have strong explanatory power for both endogenous variables (trade and institutions). As a result, they encounter problems of multicollinearity in their second stage regressions. Glaeser et al. $(2004)^{3}$ observe that the settler mortality instrument used by Acemoglu et al. (2001), Rodrik et al. (2004), and many others to identify the contributions of institutions to longrun growth have strong explanatory power for both institutions and schooling. This leads them to argue that perhaps the European migrants brought with them their stock of ideas and human capital when they migrated and not just institutions. ${ }^{4}$

Given the doubts that these studies have created about the relative importance of institutions and human capital, further research is certainly called for. Our objectives in this paper are twofold. First, is to shed some light on the issue of relative importance of institutions and human capital. Second, is to unbundle institutions beyond property rights and contracts by estimating the contributions of market creating, market regulating, market stabilising, and market legitimising institutions.

We start by bringing together the two strands of literature discussed above and making an attempt to isolate the partial effects of schooling and institutions in the very long run using the cross-sectional framework. We utilise specifications already used in the literature to achieve this goal. In doing so, we face severe problems of multicollinearity in our second stage regressions. We observe that the standard instruments used in the literature have strong predictive power over both the endogenous variables (institutions and schooling) at the first stage. This makes the fitted values of institutions and schooling highly correlated with each other and this precludes the possibility of obtaining meaningful estimates of either variables. ${ }^{5}$ This indeed is a disappointing result. As a natural reaction, we then turn to dynamic panel regressions with average growth rate over five year periods as a dependent variable. Here we do not encounter the multicollinearity problems of our cross-section analysis and we are able to isolate the partial effects of institutions and human capital. This may be because lagged levels and lagged differences of institutions are weakly correlated with current levels of schooling and vice versa. Further, the use of panel data allows us to bypass the controversy regarding the settler mortality variable in the cross-section literature.

To achieve our second objective, we utilise Rodrik's (2005) four-way classification of institutions (market creating, market regulating, market stabilising, and market legitimising institutions $)^{6}$ and identify a proxy for each of them and also estimate their contributions to growth. ${ }^{7}$ We find that strong market creating institutions characterised by the adequate protection of private property and contract enforcement are growth enhancing. Market stabilising institutions that ensure macroeconomic stability and do not undertake distortionary policies boost investor confidence and are also good for growth. We notice that there is nonlinearity in the relationship between growth and market regulating institutions. There exists a growth maximising level of market regulation beyond which it increases red tape and kills the incentive for investment. The effect of market legitimising institutions is statistically insignificant. Overall, the result holds in different sub-samples and is reasonably robust to the inclusion of additional covariates.

To summarise, we make the following contributions in this paper. First, using the Blundell and Bond (1998) dynamic panel regression we are able to isolate the partial effects of institutions and human capital on growth. Second, we adopt the Rodrik (2005) four-way classification of institutions and identify proxy for each of them and estimate their contribution to growth. This is an improvement over Acemoglu and Johnson (2005) and Knack and Keefer (1995) who only focus on 'property rights institutions' and 'contracting institutions' in a cross-section of countries.

The remainder of the paper is organised as follows. In Section 2, we present our cross-section analysis which aims to isolate the partial effects of institutions and human capital in the long run. Section 3 motivates the use of dynamic panel regression model as an alternative. In Section 4, we make an attempt to unbundle institutions. We discuss the definition of each of these institutions and identify proxy measures of each of them. In Section 5, we discuss the data. Section 6 presents the results and performs several robustness tests. Section 7 concludes.

\footnotetext{
3 In a related research Papaioannou and Siourounis (2008) show that democratisation is most likely to occur in educated and affluent societies. They also show that education is one of the key factors determining the intensity of democratic reforms and the speed of democratic transitions.

4 Acemoglu et al. (2005) challenge Glaeser et al.'s (2004) argument that the variations in schooling are a major causal factor explaining the differences in political institutions. They show that the effect of schooling on democracy disappears when country fixed effects are included in the regression. This is perhaps indicative of the presence of omitted factors influencing both schooling and democracy in the long run. They however do not deal with economic institutions in their study.

5 Dollar and Kraay (2003) also confront similar problems in their cross-section analysis when they try to isolate the partial effects of institutions and trade in the long run.

6 Similar ideas are also discussed in Rodrik (2000) and Rodrik and Subramanian (2003).

7 In a related paper Acemoglu and Johnson (2005) estimate the contributions of 'property rights institutions' and 'contracting institutions' in the very long run. Their study uses the cross-sectional method noted above. Knack and Keefer (1995) also estimate the contribution of property rights and contracting institutions to growth over the period 1974 to 1989. They use OLS to estimate their model.
} 


\section{Institutions, human capital, and growth in the long run}

In this section, we focus on our first objective. We try to isolate the partial effects of human capital and institutions on long-run growth in a cross-section of countries. As a start, here we avoid unbundling institutions as it may bring in problems of multicollinearity. We follow the existing literature and adopt the following framework:

$$
\ln y_{i T}=\alpha+\beta \ln y_{i T-500}+\gamma I_{i T}+\delta \mathbf{X}_{i T}+\varepsilon_{i} .
$$

The above is a growth regression with the current level of economic development, measured by the natural logarithm of real GDP per capita, $\ln y_{i T}$ as the dependent variable, where $i$ indexes countries and $T$ indicates the year. The explanatory

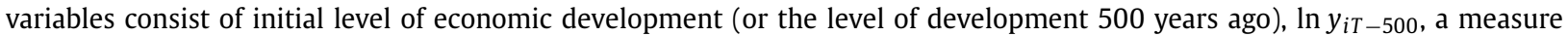
of the 'quality' of contemporary institutions, $I_{i T}$, and a vector of other explanatory variables, $\mathbf{X}_{i T}$ which includes human capital, geography, and trade. Under the assumption that the levels of development in the distant past were not too different across countries $^{8}$ the long-run growth literature generally estimates the following version of the above model

$$
\ln y_{i T}=\alpha+\gamma I_{i T}+\delta \mathbf{X}_{i T}+\varepsilon_{i} .
$$

To estimate the causal effect of institutions on long-run growth, the literature uses historical and geographical instruments. These instruments predict the historically and/or geographically determined component of institutions at the first stage and then they are used in the second stage to estimate the causal effect of institutions on long-run growth.

We adopt the same strategy and add schooling into the model to estimate partial effects of human capital and institutions. Tables $1 \mathrm{~A}$ and $1 \mathrm{~B}$ present these results. In column 1 (Panel A, Table 1A) we follow Rodrik et al. (2004) ${ }^{9}$ and estimate their preferred model using the same set of instruments as they did in their study. Rule of Law is the only statistically significant variable in this model which confirms their basic finding that institutions dominate the influence of both trade and geography as the fundamental determinant of long-run development. In column 2 we add schooling into this model and we are unable to isolate the partial effects of institutions and human capital as none of the coefficients are statistically significant. However, the $F$-test on the joint significance of schooling and rule of law reveals that they are jointly significant with a $p$-value 0.038 . To investigate the reason behind this, we look at the first stage regressions reported in columns $1 \& 2$ of Panel B. In column 1 we confirm that there is a strong partial correlation between settler mortality instrument and current rule of law-a result well documented in the literature. However, we also find that the settler mortality instrument is correlated with current schooling (see column 2) and this correlation is independent of the correlation between current schooling and current rule of law (see column 3). We observe that the correlation between fitted values of rule of law and the fitted values of schooling is as high as 0.9435 . This is perhaps causing severe multicollinearity problem in our second stage regression making all coefficients statistically insignificant.

In column 3 (Panel A, Table 1A), we follow Acemoglu et al. (2001) ${ }^{10}$ and estimate their preferred model. We also confirm their finding that institutions measured by expropriation risk has a causal effect on long-run growth. In column 4 , we add schooling in 1995 into this specification and we confront the same multicollinearity problem that we encountered in column 2. None of the coefficient estimates are statistically significant. We take a quick look at the first stage regressions (Panel B, columns 4-6). They reveal that the settler mortality instrument is as good a predictor of schooling as it is for expropriation risk and this relationship is independent of the correlation between schooling and expropriation risk. Also the correlation between fitted values of expropriation risk and schooling is as high as 0.9036. This again is causing the multicollinearity problem at the second stage.

In Table 1B we follow Acemoglu and Johnson (2005) and Easterly and Levine (2003) and estimate their preferred specifications. ${ }^{11}$ Acemoglu and Johnson (2005) evaluate the relative importance of 'property rights institutions' and 'contracting institutions' measured by 'constraint on the executive' and 'legal formalism index' respectively and find that the former have a first-order effect on long-run growth and the latter does not seem to matter. ${ }^{12}$ Easterly and Levine (2003) show that endowment measured by settler mortality, latitude, landlocked dummy, and crops/minerals dummy affect development through institutions. We confirm their findings (see Panel A, columns 1 and 3). However, we encounter the same problem of multicollinearity when we add schooling into these specifications. ${ }^{13}$ The first stage regressions of Panel B show that the standard instruments used in these specifications are as good a predictor of institutions as they are for schooling. This makes the fitted values of institutions and schooling for the second stage regressions correlated with each other-correlation coefficient of 0.9226 in case of Acemoglu and Johnson (2005) specification and correlation coefficient of 0.8562 in case of Easterly and Levine (2003) specification. This causes the multicollinearity problem at the second stage.

\footnotetext{
8 Acemoglu et al. (2002) show that around 1500 Western Europe diverged from the rest of the world in terms of standard of living. Prior to that the living standards were more or less equal across countries (see Maddison, 2004). Dollar and Kraay (2003) also make the same assumption in their study.

9 The data used is from Rodrik et al. (2004) with data on schooling from Barro and Lee (2000).

10 The data used is from Acemoglu et al. (2001) and schooling data is from Barro and Lee (2000).

11 The data used are also from Acemoglu and Johnson (2005) and Easterly and Levine (2003).

12 See Section IIA, p. 955 of Acemoglu and Johnson (2005) for an explanation on why 'constraint on the executive' and 'legal formalism index' are good proxies of 'property rights institutions' and 'contracting institutions,' respectively.

13 The only exception is the Easterly and Levine (2003) specification where we are able to isolate the partial effects of institutions and schooling (see column 4, Panel A).
} 
Table 1A

Institutions, human capital and growth in the long run

\begin{tabular}{|c|c|c|c|c|c|c|c|}
\hline \multicolumn{4}{|l|}{ Rodrik et al. (2004) } & \multicolumn{4}{|l|}{ Acemoglu et al. (2001) } \\
\hline \multicolumn{4}{|c|}{ Dependent variable: Log per capita GDP in 2000} & \multicolumn{4}{|c|}{ Dependent variable: Log per capita GDP in 1995} \\
\hline \multicolumn{8}{|l|}{ Panel A: 2SLS results } \\
\hline Explanatory variables & $\begin{array}{l}\text { Original model } \\
\text { obs }=68 \\
(1)\end{array}$ & \multicolumn{2}{|c|}{$\begin{array}{l}\text { Model with schooling } \\
\text { obs }=43 \\
(2)\end{array}$} & Explanatory variables & $\begin{array}{l}\text { Original model } \\
\text { obs }=65 \\
(3)\end{array}$ & \multicolumn{2}{|c|}{$\begin{array}{l}\text { Model with schooling } \\
\text { obs }=51 \\
(4)\end{array}$} \\
\hline Rule of Law (2001) & $\begin{array}{l}1.55^{* * *} \\
(0.2541)\end{array}$ & \multicolumn{2}{|l|}{$\begin{array}{l}3.55 \\
(6.224)\end{array}$} & $\begin{array}{l}\text { Avg protection against } \\
\text { expropriation 1985-1995 }\end{array}$ & $\begin{array}{l}0.96^{* * *} \\
(0.2227)\end{array}$ & \multicolumn{2}{|l|}{$\begin{array}{l}-2.72 \\
(104.2)\end{array}$} \\
\hline \multicolumn{2}{|l|}{$\begin{array}{l}\text { Total years of schooling } \\
(2000)\end{array}$} & \multicolumn{2}{|l|}{$\begin{array}{l}1.1 \\
(1.322)\end{array}$} & & & & \\
\hline Avg Log trade share & $\begin{array}{l}-0.47 \\
(0.2849)\end{array}$ & \multicolumn{2}{|l|}{$\begin{array}{l}2.47 \\
(4.023)\end{array}$} & \multicolumn{2}{|l|}{$\begin{array}{l}\text { Total years of schooling } \\
\text { (1995) }\end{array}$} & \multicolumn{2}{|l|}{$\begin{array}{l}1.35 \\
(38.11)\end{array}$} \\
\hline Latitude & $\begin{array}{l}-0.01 \\
(0.0140)\end{array}$ & \multicolumn{2}{|l|}{$\begin{array}{l}0.08 \\
(0.1219)\end{array}$} & \multirow{2}{*}{ Latitude } & \multirow{3}{*}{$\begin{array}{l}0.002 \\
(0.0128) \\
-\end{array}$} & \multirow{2}{*}{\multicolumn{2}{|c|}{$\begin{array}{l}0.04 \\
(1.428)\end{array}$}} \\
\hline$F$-test & & \multicolumn{2}{|l|}{$0.038^{* *}$} & & & & \\
\hline Sargan test $(p)$ & 0.10 & 0.99 & & Sargan test $(p)$ & & 0.98 & \\
\hline \multicolumn{8}{|c|}{ Panel B: First stage regressions } \\
\hline \multirow[t]{2}{*}{ Dependent variable } & \multirow{2}{*}{$\begin{array}{l}\text { Rule of Law (2001) } \\
\text { obs }=76 \\
(1)\end{array}$} & \multicolumn{2}{|c|}{ Schooling (2000) } & \multirow[t]{2}{*}{ Dependent variable } & \multirow{2}{*}{$\begin{array}{l}\text { Avg prot. against } \\
\text { expropriation } \\
\text { obs }=67 \\
(4)\end{array}$} & \multicolumn{2}{|c|}{ Schooling (1995) } \\
\hline & & $\begin{array}{l}\text { obs }=56 \\
(2)\end{array}$ & $\begin{array}{l}\text { obs }=56 \\
(3)\end{array}$ & & & $\begin{array}{l}\text { obs }=55 \\
(5)\end{array}$ & $\begin{array}{l}\text { obs }=51 \\
(6)\end{array}$ \\
\hline Log settler mortality & $\begin{array}{l}-0.25^{* * *} \\
(0.1039)\end{array}$ & $\begin{array}{l}-1.32^{* * *} \\
(0.2243)\end{array}$ & $\begin{array}{l}-0.83^{* * *} \\
(0.1923)\end{array}$ & Log settler mortality & $\begin{array}{l}-0.47^{* * *} \\
(0.1448)\end{array}$ & $\begin{array}{l}-1.39^{* * *} \\
(0.2179)\end{array}$ & $\begin{array}{l}-1.11^{* * *} \\
(0.2153)\end{array}$ \\
\hline ENGFRAC & $\begin{array}{l}0.95^{* * *} \\
(0.3311)\end{array}$ & $\begin{array}{l}2.05^{* *} \\
(0.8444)\end{array}$ & $\begin{array}{l}1.1^{*} \\
(0.6263)\end{array}$ & L. pop. den. in 1500 & & $\begin{array}{l}-0.58^{* * *} \\
(0.1333)\end{array}$ & $\begin{array}{l}-0.49^{* * *} \\
(0.1283)\end{array}$ \\
\hline EURFRAC & $\begin{array}{l}0.18 \\
(0.2197)\end{array}$ & $\begin{array}{l}1.44^{* *} \\
(0.5645)\end{array}$ & $\begin{array}{l}1.33^{* * *} \\
(0.4949)\end{array}$ & Latitude & 0.02 & 0.02 & 0.01 \\
\hline CONST & $\begin{array}{l}0.008 \\
(0.0057)\end{array}$ & $\begin{array}{l}0.002 \\
(0.0164)\end{array}$ & $\begin{array}{l}-0.026^{*} \\
(0.0141)\end{array}$ & & $(0.0155)$ & $(0.0202)$ & $(0.0189)$ \\
\hline Latitude & $\begin{array}{l}0.02^{* *} \\
(0.0088)\end{array}$ & $\begin{array}{l}0.014 \\
(0.0199)\end{array}$ & $\begin{array}{l}-0.01 \\
(0.0200)\end{array}$ & $\begin{array}{l}\text { Avg. prot. against } \\
\text { expropriation 1985-1995 }\end{array}$ & & & $\begin{array}{l}0.49^{* * *} \\
(0.1683)\end{array}$ \\
\hline Rule of Law (2001) & & & $\begin{array}{l}1.29^{* * *} \\
(0.2949)\end{array}$ & & & & \\
\hline$R^{2}$ & 0.5472 & 0.7311 & 0.8061 & $R^{2}$ & 0.2553 & 0.7195 & 0.7692 \\
\hline$F$-stat & 21.54 & 33.57 & & F-stat & 10.97 & 43.61 & \\
\hline
\end{tabular}

Notes. Figures in the parentheses are the respective standard errors. Joint $F$-test $p$ value of Rule of Law and Schooling is reported in column 2, Panel A. The standard errors are heteroskedasticity robust. L. pop. den. in 1500 is log population density in 1500, ENGFRAC is fraction of population speaking English, EURFRAC is fraction of population speaking European languages. In Panel B the dependent variables are Rule of Law (2001), Schooling (2000), Average protection against expropriation, and schooling (1995).

*** Indicates significance level of $1 \%$ against a two-sided alternative.

** $\quad$ Ibid., $5 \%$.

Ibid., $10 \%$.

Therefore it appears that the cross-sectional data is not ideal for separating out the partial effects of institutions and human capital on long-run growth. ${ }^{14}$ This is because the fitted values of the endogenous variables in the second stage of a 2SLS regression can be highly correlated with each other given the set of instruments used. Multicollinearity at the second stage blows up the standard errors making all coefficient estimates statistically insignificant. ${ }^{15}$ However, we may end up with an entirely different result if a different instrument set is used. Hence, the appropriate interpretation is that the regressions are simply uninformative as it provides no information that would alter our theoretical priors one way or the other. In other words, based on these results we are unable to comment on the relative importance of institutions and human capital to growth. This is indeed very negative and disappointing result. However, there are ways that we can pursue to proceed from here. One way is to search for alternative instruments for institutions and human capital which are more orthogonal to each other so that they can make the fitted values of institutions and human capital at the second stage more independent. But this is not an easy task as good instruments are hard to find. Alternatively, we can exploit the time series variation in human capital, institutions, and growth and try to estimate the partial effects. In that case, we can rely on the possibility that lagged levels and lagged differences of institutions are weakly correlated with current levels of schooling but strongly correlated with current levels of institutions and vice versa. This will allow us to use them as valid instruments,

\footnotetext{
14 We encounter a similar problem of multicollinearity when we try to isolate the partial effects of human capital and institutions on growth fluctuation using the Acemoglu et al. (2003) specification. Results are available upon request.

15 In this sense, the problem is also related to a more general critique of the empirical growth literature by Levine and Renelt (1992) who show that all growth enhancing factors are correlated with each other and also with omitted factors which makes it difficult to estimate the separate effects of these factors on growth using a cross-sectional dataset.
} 
Table 1B

Institutions, human capital and growth in the long run

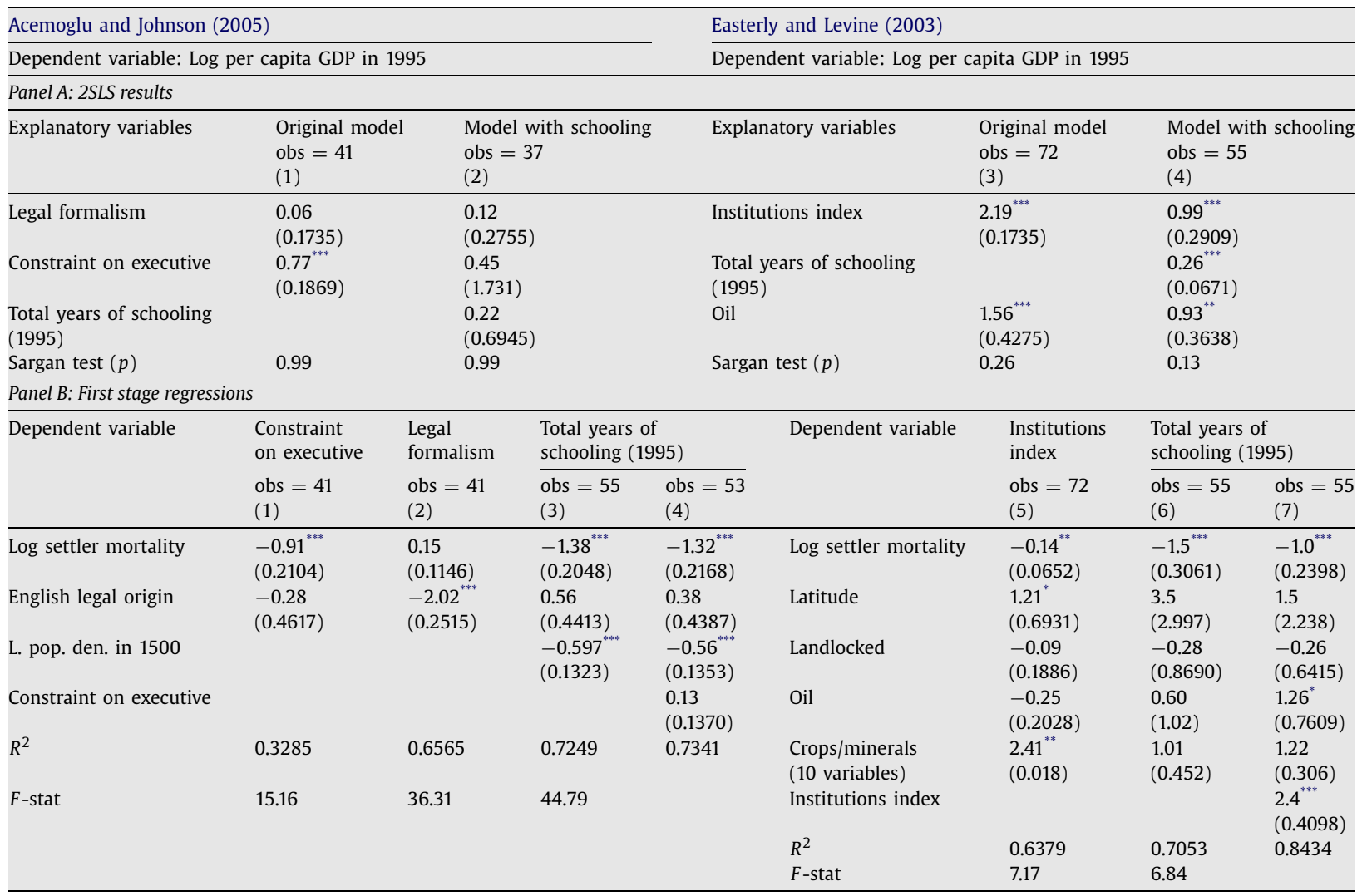

Notes. Figures in the parentheses are the respective standard errors. For Crops/minerals (10 variables) the table reports $F$-test of joint significance of the individual variables with $p$-value in parentheses. English legal origin is used as an instrument for Legal formalism in Acemoglu and Johnson (2005). L. pop. den. in 1500 is log population density in 1500. In Panel B the dependent variables are Constraint on executive, Legal formalism, Institutions index, and Total years of schooling (1995).

*** Indicates significance level at $1 \%$ against a two-sided alternative.

** Ibid., 5\%.

* Ibid., $10 \%$

bypass the problem of multicollinearity, and also the controversy regarding the settler mortality instrument. An additional advantage of using a panel dataset is that we can eliminate the omitted factors influencing growth, institutions, and human capital by differencing the data.

\section{Institutions, human capital, and growth in a dynamic panel data model}

The model that we estimated in Section 2 focuses on growth in the very long run. But we are confronted with the problem of multicollinearity in our second stage which made the estimation of partial effects of institutions and human capital extremely difficult. As a natural response we shift to a dynamic framework which estimates the impact of institutions and human capital on average growth over a five year period. The estimation process uses lagged differences and lagged levels of institutions, human capital, income, and trade as instruments. Therefore, we would expect that the lagged differences and lagged levels of institutions to be more orthogonal to the lagged differences and lagged levels of human capital and hence reduce the problem of multicollinearity in the second stage which we experienced in our cross-sectional analysis. Moreover, exploiting the time dimension of the dataset will also allow us to abstract from the influence of all time invariant unobserved factors that explain cross-country differences in growth.

We start with a growth model similar to Eq. (1). The differences are that it covers relatively shorter time horizon and we include quality of institutions variable inside $\mathbf{Z}_{i T}$ vector to save space. The model is as follows:

$$
\ln y_{i T}=\beta_{0}+\beta_{1} \ln y_{i T-5}+\beta_{2}^{\prime} \mathbf{Z}_{i T}+\eta_{i}+u_{i T}
$$


where $\mathbf{Z}_{i T}$ is a set of control variables which includes institutions, human capital, and trade ${ }^{16}$ and which are measured as averages over the period $T$ to $T-5$. By subtracting $\ln y_{i T}$ from both sides and dividing throughout by [T $\left.-(T-5)\right]$ we get:

$$
\hat{y}_{i T}=\theta_{0}+\theta_{1} \ln y_{i T-5}+\theta_{2}^{\prime} \mathbf{Z}_{i T}+\mu_{i}+v_{i T}
$$

where $\hat{y}_{i T}=\frac{1}{5}\left(\ln y_{i T}-\ln y_{i T-5}\right), \theta_{0}=\frac{\beta_{0}}{5}, \theta_{1}=\frac{\beta_{1}-1}{5}, \theta_{2}^{\prime}=\frac{\beta_{2}^{\prime}}{5}$ and $\mu_{i}=\frac{\eta_{i}}{5}, v_{i T}=\frac{u_{i T}}{5}$. Following Caselli et al. (1996) and differencing ${ }^{17} \mathrm{Eq}$. (4) we get the following regression:

$$
\hat{y}_{i T}-\hat{y}_{i T-5}=\theta_{1}\left(\ln y_{i T-5}-\ln y_{i T-10}\right)+\theta_{2}^{\prime}\left(\mathbf{Z}_{i T}-\mathbf{Z}_{i T-5}\right)+\left(v_{i T}-v_{i T-5}\right) .
$$

Estimating $\theta_{1}$ and $\theta_{2}^{\prime}$ by using lagged values of $\left(\ln y_{i T-5}-\ln y_{i T-10}\right),\left(\mathbf{Z}_{i T}-\mathbf{Z}_{i T-5}\right), \ln y_{i T-5}$ and $\mathbf{Z}_{i T}$ as instruments have several desirable features. First, differencing eliminates the unobserved country specific factors, $\mu_{i}$, which is a possible source of omitted variable bias. Second, the lagged differences and lagged levels of institutions and human capital included in the $\left(\mathbf{Z}_{i T-5}-\mathbf{Z}_{i T-10}\right)$ and $\mathbf{Z}_{i T-5}$ matrix respectively are less likely to be correlated with each other which reduces the likelihood of a multicollinearity problem in the second stage regressions.

For the instruments to be valid they have to be correlated with the suspected endogenous variables (all the explanatory variables in this case) but uncorrelated with the error term. In other words, they have to satisfy the following conditions ${ }^{18}$ :

$$
E\left(\hat{y}_{i T-5} \hat{y}_{i T-10}\right) \neq 0, \quad E\left(v_{i T} \hat{y}_{i T-10}\right)=0, \quad E\left(\hat{y}_{i T-5} \hat{y}_{i T-15}\right)=0 .
$$

Following Caselli et al. (1996) and others in this literature, we use the Hansen's J statistic to check whether the instruments as a group are exogenous. ${ }^{19}$ This statistic is robust to heteroskedasticity and autocorrelation. We also test the hypothesis that the error terms are not second-order serially correlated. A rejection of the null hypothesis implies that the lags of the dependent variables are endogenous and hence violates the conditions outlined in Eq. (6). The outcomes of these tests are reported in Tables 4 to 7.

In summary, the desirable features of this method are in terms of tackling the following.

- Multicollinearity. Lagged differences and lagged levels of institutions are less likely to be correlated with lagged differences and lagged levels of human capital and hence the likelihood of multicollinearity in the second stage is much smaller.

- Endogeneity. This strategy offers a natural set of internal instruments which minimises the likelihood of reverse causation from growth to institutions and growth to human capital. As long as the instruments pass the Hansen test of endogeneity, we can say that they are statistically valid.

- Omitted variable bias. Many of the omitted time invariant deep factors (culture, ethnic makeup, religion, climate) influencing growth can be correlated with institutions and human capital. This has the potential of causing omitted variable bias. This strategy allows us to eliminate the influence of these factors by differencing the data. Of course there are other variables which can influence growth, institutions, and human capital. Some of the obvious ones are investment share, population growth, foreign aid, and foreign direct investment (FDI). We try to control for them as a robustness check. However, we can never be entirely sure that we have adequately controlled for all the omitted factors.

Our main focus is on the estimate of $\theta_{2}^{\prime}$. This estimate can be interpreted as the effect of human capital, institutions, and other factors on growth (see Eq. (4)). It can also be interpreted as the effect of changes in human capital and institutions on changes in growth (see Eq. (5)). ${ }^{20}$ We choose the former so that our results are comparable with other studies in the empirical growth literature.

\section{Unbundling institutions}

We adopt the Rodrik (2005) four-way classification (market creating, market regulating, market stabilising, and market legitimising) of institutions and include them as controls in our $\mathbf{Z}_{i T}$ matrix. Majority of the contemporary literature focuses on the importance of property rights and contracts in creating the right incentive structure for investment and entrepreneurship. But long run economic growth requires more than just a boost in investment or entrepreneurship. To sustain growth momentum requires institutions which can facilitate exchange in a world of imperfect information, handle random shocks to the economy, and facilitate socially acceptable burden sharing in the event of a shock. The four-way classification attempts to cover all aspects of institutions and also distinguish them on the basis of their functions.

Market creating institutions are those that protect property rights and ensure contract enforcement. They are called market creating since, in their absence, either the markets do not exist or they perform very poorly. Ideally one would

\footnotetext{
16 Dollar and Kraay (2003) find evidence of a significant effect of trade on growth even in the presence of institutions. Hence we control for trade in our model.

17 Differencing allows us to eliminate the country specific unobserved heterogeneity $\mu_{i}$.

18 See Caselli et al. (1996) and Blundell and Bond (1998) for a more detailed discussion of this approach.

19 If the instruments as a group are not exogenous then the estimator yields biased estimates.

20 Dollar and Kraay (2003) adopts this style of interpretation.
} 
expect expropriation risk or executive constraint to be good measures of market creating institutions. But they are not entirely suitable for our purpose as we will see below. As an alternative, we choose the ICRG law and order index. ${ }^{21}$ The underlying assumption is that a country with strong law and order is expected to have better property rights and contract enforcement. The 'law' subcomponent of the measure assesses the strength and impartiality of the legal system and the 'order' subcomponent is an assessment of popular observance of the law. The assessment is made on a six point scale with a high score implying better law and order. We observe that 79 per cent of the variation in law and order is between countries and the remainder 21 per cent is within countries. Sri Lanka ranks lowest on law and order with a score of 0.3 in 1990 and Luxembourg ranks highest with a score of 6 all throughout the period. One would expect better law and order would lead to less risk of expropriation and better contract enforcement.

There are at least four other measures that has been used as a proxy for market creating institutions in the literaturerule of law index of Rodrik et al. (2004), expropriation risk of Acemoglu et al. (2001), executive constraint and legal formalism index of Acemoglu and Johnson (2005). ${ }^{22}$ Acemoglu and Johnson (2005) use executive constraint as a proxy for property rights institutions and legal formalism as a proxy for contracting institutions to separately estimate their effects on long-run growth. Therefore, the obvious question is why we choose ICRG law and order index as our preferred measure. Even though far from perfect, there are at least two clear cut advantages of using the law and order index. First, it has a long enough time dimension running from 1984 to 2004 which is useful for the dynamic panel data estimation. In contrast, the rule of law index of Rodrik et al. (2004) and legal formalism index of Acemoglu and Johnson (2005) are only available in cross-section and the expropriation risk measure of Acemoglu et al. (2001) only covers the period 1982 to 1997 which is too short time dimension for estimating our dynamic panel model. Second, it can be counted upon as a measure that represents both property rights and contracting institutions. We however check the robustness of our result using alternative measures of institutions.

The other question is why we choose not to separate out the effects of property rights and contracts. This is largely due to our failure to find a reasonable proxy for contracting institutions. Acemoglu and Johnson (2005) argue that an ideal measure of contracting institutions is the cost of enforcing private contracts. They use legal formalism index as a proxy. This measure however is not available in a panel. As an alternative we use repudiation of government contracts which measures the cost of enforcing government contracts and it is far from ideal. ${ }^{23}$ It primarily focuses on institutions that define the relationship between the state and its subjects and not on institutions that provide the legal framework that enables private contracts to facilitate economic transactions. This measure also drastically reduces our sample size. Nevertheless, we report these findings in Section 6.

Market regulating institutions are those that prevent market failure and help to sustain the growth momentum over the long-run. Rodrik and Subramanian (2003) mention regulatory agencies in telecommunication, transport, and financial services as examples of market regulating institutions. We proxy this by using Gwartney and Lawson's (2005) composite index of regulation $(M R)$ in the credit market, labour market, and business in general since this is the closest to their examples. The index operates on an eleven point scale ranging from 0 to 10 with a high score implying fewer regulations. We observe that 67 per cent of the variation in the measure is between countries. Romania records the lowest level of regulation and New Zealand records the highest level of regulation in the dataset. This is the only proxy of regulatory institutions that we could locate which has the desirable time dimension.

Market stabilising institutions are those that build resilience towards shocks, reduce inflationary pressure, minimises macroeconomic volatility and averts financial crises. Examples of market stabilising institutions include central bank, exchange rate regime, and budgetary and fiscal rules. Finding a suitable proxy for this is a challenge. We thought that it is not unreasonable to assume that good market stabilising institutions (independent central banks) do look to minimise inflationary pressure and volatility in the long run. ${ }^{24}$ Hence, we use Gwartney and Lawson's (2005) sound money index (SM) as a proxy which takes into account: (a) average annual growth of the money supply in the last five years minus average annual growth of real GDP in the last ten years, (b) standard inflation variability in the last five years, and (c) recent inflation rate. This index also ranges from 0 to 10 with a high score implying better market stabilising institutions. We observe that 56 per cent of the variation in market stabilising institutions is between variation. Canada, France, Denmark, Switzerland are among countries with very strong 'market stabilising institutions' whereas some of the Latin American countries including Argentina and Brazil fare among the worst especially during the 1980s.

Market legitimising institutions are those that handle redistribution, manage social conflict, and provide social protection and insurance in the event of a shock. In other words, it helps to minimise the idiosyncratic risk to economic growth and employment in a modern market economy. Rodrik (2005) suggest democracy as a proxy for market legitimising institutions as there is a positive relationship between the effectiveness of democratic institutions and the quality of social insurance. Therefore, the Polity IV democracy index suits our purpose as it measures the effectiveness of democratic institutions by capturing different shades of democracy and it ranges from 0 to 10 with a high score implying more democratic system.

\footnotetext{
21 ICRG law and order index is also used by Alesina and Dollar (2000) as a measure of institutions.

22 Hall and Jones (1999) uses social infrastructure index as an overall measure of institutions. They combine law and order, bureaucratic quality, corruption, risk of expropriation, and government repudiation of contracts from ICRG and the Sachs and Warner (1995) index of openness to construct the index. This however is not suitable for our purpose of unbundling institutions. Also the Sachs and Warner openness index is not a measure of institutions.

23 Knack and Keefer (1995) use this as a measure of contracting institutions.

24 Barro (1995) reports negative relationship between inflation and central bank independence in a cross-section of countries.
} 
Table 2

Summary statistics

\begin{tabular}{|c|c|c|c|c|c|}
\hline Variable & Number of obs. & Mean & Standard deviation & Minimum & Maximum \\
\hline \multicolumn{6}{|l|}{ Economic growth and development } \\
\hline Growth $\left(\hat{y}_{i T}\right)$ & 629 & 0.014 & 0.031 & -0.10 & 0.35 \\
\hline Initial income $\left(y_{i T-5}\right)$ & 629 & 8.4 & 1.13 & 6.01 & 10.88 \\
\hline \multicolumn{6}{|l|}{ Market creating institutions } \\
\hline Law and Order (LO) & 507 & 3.7 & 1.5 & 0.3 & 6 \\
\hline \multicolumn{6}{|l|}{ Market regulating institutions } \\
\hline Regulation of Credit, Labour, Business (MR) & 616 & 5.6 & 1.1 & 2.5 & 8.8 \\
\hline \multicolumn{6}{|l|}{ Market stabilising institutions } \\
\hline Sound Money Index (SM) & 634 & 7.5 & 2.5 & 0 & 9.8 \\
\hline \multicolumn{6}{|l|}{ Market legitimising institutions } \\
\hline Democracy Index (DEMOC) & 659 & 5.0 & 4.1 & 0 & 10 \\
\hline \multicolumn{6}{|l|}{ Schooling } \\
\hline Total years of schooling (TYS) & 482 & 5.4 & 2.9 & 0.4 & 12.3 \\
\hline \multicolumn{6}{|l|}{ Trade openness } \\
\hline Log trade share of GDP (LTRS) & 754 & 4.19 & 0.59 & 2.43 & 6.01 \\
\hline
\end{tabular}

Among the most democratic nations are United States, Japan, United Kingdom and among the least democratic are Morocco, Nigeria, Equatorial Guinea in the dataset. 78 per cent of the variation in this series is between countries and 22 per cent of the variation is within countries. Several previous studies (see Barro, 1996; Rodrik, 1999; Tavares and Wacziarg, 2001; Acemoglu et al., 2005, in press; and many others) use this as a measure of democracy. We also use the freedom house political rights index as an alternative measure of market legitimising institutions. ${ }^{25}$

There is also a strong view in this literature that a simple dichotomy between democracy and nondemocracy is the most appropriate empirical definition (see Przeworski et al., 2000). However, this definition is not suitable for our purpose as it does not provide any information on the effectiveness of democratic institutions. Recently, Persson and Tabellini (2006) use a similar empirical definition and look at the impact of regime change and different styles of democracy on within country growth. They find that countries liberalising their economy before extending political rights do better in terms of growth than countries following the opposite sequence. Their measure also focuses on democratic transitions and hence is not suitable for our purpose.

Finally, there is a view in the literature that corruption should be treated as an institution. Hall and Jones (1999) and Knack and Keefer (1995) include corruption in their overall measure of institutions. We however are a bit sceptical about classifying corruption as an institution. In our view corruption is the outcome of poor market creating institutions rather than an institution itself. This is perhaps reflected by the measure of corruption that Mauro (1995) uses. Mauro (1995) uses an indicator that reflects experts' assessments of the degree to which business transactions involve corruption or questionable payments averaged over the period 1980-1983. This is an index of perception and is reflective of institutional outcome rather than institutions themselves. Nevertheless, we do include ICRG index of corruption as an additional control variable (see Table 6, column 3) and our basic results are robust to this inclusion.

\section{Data}

The dataset includes measures of schooling, institutions, per capita GDP growth, per capita GDP levels, and trade share. There are six time points in the data spanning over the period 1980-2004 with each time point being approximately five year averages. There are missing observations in the data and hence we have an unbalanced panel.

We follow the literature and proxy human capital using schooling data from Barro and Lee (2000). It measures the average schooling years in the total population. 96 per cent of the variation in schooling is between countries.

As indicated in the previous section we use four different measures of institutions. There are a number of conceptual and empirical challenges that we face in our analysis. It is hard to rule out the potential overlaps between these measures of institutions. The pairwise correlations reported in Table 3 shows that the measures of institutions are correlated. The correlation between law and order and democracy is 0.5321 and the correlation between democracy and the regulation of credit, labour, and business is 0.5066 . However, none of the correlations are large enough to cause any serious problems of multicollinearity.

The GDP per capita purchasing power parity (PPP) measured at constant 2000 international dollars is obtained from the World Development Indicator (WDI). The WDI data provides larger time coverage and allows us to extend the study to 2004. Annualised growth rates of GDP per capita are calculated using the formula $\hat{y}_{i T} \equiv \frac{1}{5}\left(\ln y_{i T}-\ln y_{i T-5}\right)$.

The trade share measure is also from WDI and is widely used (see Dollar and Kraay, 2003; Rodrik et al., 2004; and many others). It is perhaps the simplest measures of trade openness where trade is expressed as a share of GDP.

Table 2 presents the descriptive statistics for the important variables used in the study.

\footnotetext{
25 This measure is suitable since it ranges from 1 to 7 and distinguishes between different shades of democracy.
} 
Table 3

Unbundled institutions, human capital and growth: pairwise correlation

\begin{tabular}{|c|c|c|c|c|c|c|c|c|}
\hline & $\begin{array}{l}\text { Growth } \\
\left(\hat{y}_{i T}\right)\end{array}$ & $\begin{array}{l}\text { Initial income } \\
\left(y_{i T-5}\right)\end{array}$ & $\begin{array}{l}\text { Law and } \\
\text { Order (LO) }\end{array}$ & $\begin{array}{l}\text { Democracy } \\
\text { (DEMOC) }\end{array}$ & $\begin{array}{l}\text { Sound Money } \\
\text { Index }(S M)\end{array}$ & $\begin{array}{l}\text { Regulation of } \\
\text { Credit, Labour, } \\
\text { Business }(M R)\end{array}$ & $\begin{array}{l}\text { Total years } \\
\text { of schooling } \\
\text { (TYS) }\end{array}$ & $\begin{array}{l}\text { Log trade } \\
\text { share of GDP } \\
\text { (LTRS) } \\
\end{array}$ \\
\hline Growth $\left(\hat{y}_{i T}\right)$ & 1.0000 & & & & & & & \\
\hline Initial income $\left(y_{i T-5}\right)$ & 0.1887 & 1.0000 & & & & & & \\
\hline Law and Order (LO) & 0.3631 & 0.7243 & 1.0000 & & & & & \\
\hline Democracy (DEMOC) & 0.1639 & 0.6824 & 0.5321 & 1.0000 & & & & \\
\hline Sound Money Index (SM) & 0.3075 & 0.2753 & 0.3770 & 0.1796 & 1.0000 & & & \\
\hline $\begin{array}{l}\text { Regulation of Credit, } \\
\text { Labour, Business (MR) }\end{array}$ & 0.1812 & 0.4437 & 0.4287 & 0.5066 & 0.4089 & 1.0000 & & \\
\hline Total years of schooling (TYS) & 0.3071 & 0.8511 & 0.7217 & 0.6237 & 0.2746 & 0.4899 & 1.0000 & \\
\hline Log trade share of GDP (LTRS) & 0.1729 & 0.1250 & 0.1969 & 0.0626 & 0.2707 & 0.2740 & 0.1497 & 1.0000 \\
\hline
\end{tabular}

Table 4

Unbundled institutions, human capital and growth: dynamic regressions

\begin{tabular}{|c|c|c|c|c|c|c|c|c|c|}
\hline & \multicolumn{9}{|c|}{ Dependent variable: annualised growth $\left(\hat{y}_{i T}\right)$} \\
\hline & $\overline{(1)}$ & $(2)$ & (3) & $(4)$ & (5) & (6) & (7) & $(8)$ & (9) \\
\hline Law and Order (LO) & $\begin{array}{l}0.004^{* *} \\
(0.0020)\end{array}$ & & & & $\begin{array}{l}0.005^{* *} \\
(0.0020)\end{array}$ & & $\begin{array}{l}0.005^{* *} \\
(0.0020)\end{array}$ & $\begin{array}{l}0.005^{* * *} \\
(0.0018)\end{array}$ & $\begin{array}{l}0.005^{* * *} \\
(0.0018)\end{array}$ \\
\hline $\begin{array}{l}\text { Executive constraint } \\
\text { (EXCONST) } \\
\text { Repudiation of Govt. } \\
\text { contracts (REPU) }\end{array}$ & & & & & & $\begin{array}{l}0.012^{* * *} \\
(0.0042) \\
0.007^{* * *} \\
(0.0017)\end{array}$ & & & \\
\hline $\begin{array}{l}\text { Regulation of Credit, Labour, } \\
\text { Business }(M R)\end{array}$ & & $\begin{array}{l}-0.001 \\
(0.0029)\end{array}$ & & & $\begin{array}{l}-0.003 \\
(0.0024)\end{array}$ & $\begin{array}{l}-0.006^{*} \\
(0.0036)\end{array}$ & $\begin{array}{l}0.023 \\
(0.0153)\end{array}$ & $\begin{array}{l}-0.003 \\
(0.0025)\end{array}$ & $\begin{array}{l}0.023 \\
(0.0148)\end{array}$ \\
\hline Sound Money Index (SM) & & & $\begin{array}{l}0.003^{* * *} \\
(0.0009)\end{array}$ & & $\begin{array}{l}0.003^{* * *} \\
(0.0009)\end{array}$ & $\begin{array}{l}0.002 \\
(0.0013)\end{array}$ & $\begin{array}{l}0.002^{* *} \\
(0.0009)\end{array}$ & $\begin{array}{l}0.003^{* * *} \\
(0.0009)\end{array}$ & $\begin{array}{l}0.002^{* *} \\
(0.0009)\end{array}$ \\
\hline Democracy Index (DEMOC) & & & & $\begin{array}{l}0.0004 \\
(0.0011)\end{array}$ & $\begin{array}{l}-0.0003 \\
(0.0009)\end{array}$ & $\begin{array}{l}-0.007^{* * *} \\
(0.0026)\end{array}$ & $\begin{array}{l}-0.001 \\
(0.0010)\end{array}$ & $\begin{array}{l}0.001 \\
(0.0021)\end{array}$ & $\begin{array}{l}0.0003 \\
(0.0021)\end{array}$ \\
\hline Total years of schooling (TYS) & $\begin{array}{l}0.004 \\
(0.0029)\end{array}$ & $\begin{array}{l}0.007^{* *} \\
(0.0034)\end{array}$ & $\begin{array}{l}0.005^{*} \\
(0.0028)\end{array}$ & $\begin{array}{l}0.01^{* *} \\
(0.0038)\end{array}$ & $\begin{array}{l}0.006^{* *} \\
(0.0026)\end{array}$ & $\begin{array}{l}0.006^{*} \\
(0.0034)\end{array}$ & $\begin{array}{l}0.007^{* * *} \\
(0.0024)\end{array}$ & $\begin{array}{l}0.005^{* *} \\
(0.0025)\end{array}$ & $\begin{array}{l}0.006^{* * *} \\
(0.0024)\end{array}$ \\
\hline$M R^{2}$ & & & & & & & $\begin{array}{l}-0.002^{*} \\
(0.0013)\end{array}$ & & $\begin{array}{l}-0.002^{*} \\
(0.0013)\end{array}$ \\
\hline DEMOC $^{2}$ & & & & & & & & $\begin{array}{l}-0.0001 \\
(0.0002)\end{array}$ & $\begin{array}{l}-0.0001 \\
(0.0002)\end{array}$ \\
\hline Other controls & & & & & & & & & \\
\hline Initial income $\left(y_{i T-5}\right)$ & YES & YES & YES & YES & YES & YES & YES & YES & YES \\
\hline $\begin{array}{l}\text { Log trade share (LTRS) } \\
\text { Specification tests ( } p \text {-values) }\end{array}$ & YES & YES & YES & YES & YES & YES & YES & YES & YES \\
\hline Joint $F$-test (Institutions) & & & & & 0.0027 & 0.0000 & 0.0079 & 0.0030 & 0.0044 \\
\hline Hansen test & 0.060 & 0.109 & 0.009 & 0.157 & 0.351 & 0.480 & 0.670 & 0.776 & 0.866 \\
\hline Test for $\mathrm{AR}(1)$ in residuals & 0.001 & 0.001 & 0.000 & 0.001 & 0.001 & 0.034 & 0.002 & 0.001 & 0.002 \\
\hline Test for $\operatorname{AR}(2)$ in residuals & 0.291 & 0.325 & 0.032 & 0.251 & 0.174 & - & 0.166 & 0.175 & 0.174 \\
\hline Observations/countries & $348 / 87$ & $363 / 93$ & $369 / 93$ & $370 / 95$ & $323 / 83$ & $242 / 83$ & $323 / 83$ & $323 / 83$ & $323 / 83$ \\
\hline
\end{tabular}

Notes. Standard errors are reported in the parenthesis. Hansen test is the test of the $H_{0}$ : the instruments as a group are exogenous. Hansen test statistic from two step Arellano \& Bond estimations is reported which is robust to heteroskedasticity or autocorrelation. Arellano and Bond AR(1) \& AR(2) tests in residuals are also reported. Note that to pass these tests, one has to reject the null of no AR(1) and fail to reject the null of no AR(2).

*** Indicates significance level of $1 \%$ against a two-sided alternative.

** Ibid., $5 \%$.

Ibid., $10 \%$.

\section{Evidence}

Table 4 reports the dynamic regressions. They are estimated using GMM Blundell and Bond estimator. In column 1 we start with a simple specification regressing law and order and schooling on growth. The other control variables are initial income and trade. In this specification, law and order is statistically significant but schooling is not. This may be due to endogeneity of the instruments as they fail the Hansen J test ( $p$ value 0.006 ). In column 2 we replace law and order by $M R$ and we observe that schooling is statistically significant but $M R$ is statistically insignificant. In column 3 we replace $M R$ by $S M$. In this specification both schooling and $S M$ are statistically significant. In column 4 we replace SM by democracy. Schooling is still statistically significant but democracy is statistically insignificant. In column 5 we estimate our preferred model with full set of control variables. We add schooling, law and order, $M R$, SM, democracy, trade, and initial income into the specification. We find that schooling, law and order and $S M$ are statistically significant and all institution measures are jointly significant. One sample standard deviation increase in schooling increases the annual growth rate in an average country by 1.7 percentage points. MR and democracy does not seem to matter. Comparable increases in law and order and $S M$ have growth effects of 0.75 percentage points and 0.75 percentage points respectively. In column 6 , we make an attempt 
to unbundle market creating institutions and separate out the effects of property rights and contracting institutions. We follow Acemoglu and Johnson (2005) and use executive constraint from the Polity IV dataset as a measure of property rights institutions. In the absence of time series data on legal formalism index we use repudiation of government contracts as an alternative measure of contracting institutions which of course is far from ideal. We observe that both property rights and contracts have positive and statistically significant effects on growth. This is in contrast with Acemoglu and Johnson (2005) who report that property rights matter more than contracts for growth in the long run. The magnitude of the coefficient on schooling remains unchanged and is statistically significant. However, a major drawback of this specification is that it drastically reduces the sample size. In this case, $T=2$ and the estimates are equivalent to 2SLS and they can be poorly identified or suffer from weak instrument problems (Wooldridge, 2002). In order to explore the possibility of nonlinearity in $M R$ we introduce $M R^{2}$ in column 7. The public interest theory of Pigou (1938) suggests that unregulated markets are comparatively more prone to failure and should be associated with socially inferior outcomes. In contrast, the public choice theory of Shleifer and Vishny (1998) suggests that regulation leads to corruption and hence is harmful for development. ${ }^{26}$ Therefore, it is possible that there is an optimum level of regulation. In other words, the relationship between regulation and growth is nonlinear and hence it justifies our inclusion of $M R^{2}$ in column 7. We observe that the coefficient on $M R^{2}$ is negative and statistically significant but the coefficient on $M R$ is positive and statistically insignificant. This is perhaps because of the nonlinear effect of regulation. In other words, perhaps there is a particular level of regulation that maximises growth. This level turns out to be 4.9 when we equate the partial derivative of growth with respect to MR to zero. ${ }^{27}$ One possible interpretation of this result is that too much or too little regulation is not good for growth. Too little regulation encourages anti-competitive behaviour among the firms and can lead to market failure. Too much regulation on the other hand can lead to red tape which has tangible costs to the economy. However, we treat this result with caution as the coefficient on $M R$ is statistically insignificant. In column 8, we make an attempt to check for nonlinearity in democracy by adding democracy ${ }^{2}$ into our preferred model. We find that the statistical significance of schooling, law and order, and SM survives but both democracy and democracy ${ }^{2}$ are statistically insignificant. In column 9 , we add both $M R^{2}$ and democracy ${ }^{2}$ into our preferred model. The effect schooling, law and order, and SM survives. The nonlinear effect of MR also survives.

To summarise, we find that both human capital proxied by schooling and institutions have positive and statistically significant effects on growth. The effect of human capital is relatively larger in size compared to the effect of institutions. Among institutions market creating institutions proxied by law and order and market stabilising institutions proxied by $S M$ have positive and equal effects on growth. Regulatory institutions proxied by MR seem to matter only to a certain extent and market legitimising institutions proxied by democracy does not seem to matter. This holds even when we use Freedom House Political Rights index as a measure of democracy. ${ }^{28}$ The democracy result is in conformity with the existing evidence in the literature. Previous studies have documented that the evidence in favour of democracy yielding subsequent growth is at best weak (see Barro, 1996; Przeworski et al., 2000; Acemoglu et al., in press).

In Table 5 we deal with an important technical issue. Is the use of Blundell and Bond estimation technique appropriate? Nickell (1981) shows that when fixed effects are correlated with explanatory variables then OLS overestimates the effect of the lagged dependent variable, fixed effect underestimates it and system GMM should be in between. In a recent Monte Carlo study, Hauk and Wacziarg (2004) show that fixed effect and Arellano and Bond GMM can in fact overestimate the effect of lagged dependent variable and bias towards zero the effect of other variables in the presence of measurement error. They show that OLS and Blundell and Bond perform the best in this situation. The advantage of Blundell and Bond over OLS is that it tackles the endogeneity problem better. Our results match with Hauk and Wacziarg (2004) as we notice in columns 2 and 3 of Table 5 that fixed effect and Arellano and Bond overestimates the effect of the lagged dependent variable ( -0.05 and -0.08 respectively) and underestimates the contribution of schooling ( 0.003 and 0.002 respectively). In case of Arellano and Bond the effect of schooling is statistically insignificant. Furthermore, the Hansen test statistic in this case also documents the weak instrument problem with Arellano and Bond when there is a short panel with persistence in the data. Therefore, the evidence suggests that GMM Blundell and Bond is the appropriate way to go.

Table 6 reports robustness results of our preferred model with additional covariates. We add additional covariates (investment and population growth, corruption, FDI, foreign aid, real exchange rate distortions, and credit to the private sector) ${ }^{29}$ and we find that our schooling, law and order, and SM result survives. Column 1 reports the preferred specification. In column 2 we add Solow style variables (investment share and population growth) as additional controls. The law and order and schooling result survives as these variables register positive and statistically significant effects on growth. The magnitude of the effects on growth however reduces by 0.1 percentage points in case of law and order and by 0.58 percentage points in case of schooling. This implies that there is an upward bias in our estimates in the absence of these variables. However, the extent of the bias is not severe enough to alter the direction and statistical significance of the effects. In column 3, we control for corruption. Coefficients on law and order, schooling, and SM survive this test. This indicates that including corruption into our set of institutions will not alter our major result. In columns 4 to 7 we examine the effect of adding FDI, foreign aid, real exchange rate distortion, and credit to the private sector respectively. Credit to the private sector is used as a proxy for financial liberalisation in the literature (Levine et al., 2000). In all the cases our main result survives.

\footnotetext{
26 See Djankov et al. (2002) for a survey of this literature.

27 The value 4.9 lies well within the sample range of $M R$ (which is 0 to 10 ).

28 We do not report this result to save space. But it is available on request.

29 Previous studies have reported strong correlation between these variables and growth.
} 
Table 5

Is the Blundell and Bond method appropriate?

\begin{tabular}{|c|c|c|c|c|}
\hline & \multicolumn{4}{|c|}{ Dependent variable: annualised growth $\left(\hat{y}_{i T}\right)$} \\
\hline & $\begin{array}{l}\text { Pooled OLS } \\
\text { (1) }\end{array}$ & $\begin{array}{l}\text { Fixed effect } \\
(2)\end{array}$ & $\begin{array}{l}\text { GMM Arellano \& Bond } \\
\text { (3) }\end{array}$ & $\begin{array}{l}\text { GMM Blundell \& Bond } \\
(4)\end{array}$ \\
\hline Initial income $\left(y_{i T-5}\right)$ & $\begin{array}{l}-0.01^{* * *} \\
(0.0025)\end{array}$ & $\begin{array}{l}-0.05^{* * *} \\
(0.0059)\end{array}$ & $\begin{array}{l}-0.08^{* * *} \\
(0.0117)\end{array}$ & $\begin{array}{l}-0.01^{*} \\
(0.0063)\end{array}$ \\
\hline Law and Order (LO) & $\begin{array}{l}0.005^{* * *} \\
(0.0012)\end{array}$ & $\begin{array}{l}0.004^{* * *} \\
(0.0013)\end{array}$ & $\begin{array}{l}0.004^{* *} \\
(0.0015)\end{array}$ & $\begin{array}{l}0.005^{* *} \\
(0.0020)\end{array}$ \\
\hline Regulation of Credit, Labour, Business (MR) & $\begin{array}{l}-0.001 \\
(0.0015)\end{array}$ & $\begin{array}{l}0.001 \\
(0.0018)\end{array}$ & $\begin{array}{l}0.004^{* *} \\
(0.0021)\end{array}$ & $\begin{array}{l}-0.003 \\
(0.0024)\end{array}$ \\
\hline Sound Money Index (SM) & $\begin{array}{l}0.002^{* * *} \\
(0.0005)\end{array}$ & $\begin{array}{l}8.5 e-04 \\
(0.0006)\end{array}$ & $\begin{array}{l}1 e-05 \\
(0.0007)\end{array}$ & $\begin{array}{l}0.003^{* * *} \\
(0.0009)\end{array}$ \\
\hline Democracy Index (DEMOC) & $\begin{array}{l}3 e-04 \\
(0.0005)\end{array}$ & $\begin{array}{l}4 e-04 \\
(0.0005)\end{array}$ & $\begin{array}{l}8 e-05 \\
(0.0007)\end{array}$ & $\begin{array}{l}-3 e-04 \\
(0.0009)\end{array}$ \\
\hline Total years of schooling (TYS) & $\begin{array}{l}0.003^{* * *} \\
(0.0009)\end{array}$ & $\begin{array}{l}0.003^{*} \\
(0.0017)\end{array}$ & $\begin{array}{l}0.002 \\
(0.0029)\end{array}$ & $\begin{array}{l}0.006^{* *} \\
(0.0026)\end{array}$ \\
\hline Log trade share (LTRS) & $\begin{array}{l}0.003 \\
(0.0024)\end{array}$ & $\begin{array}{l}0.024^{* * *} \\
(0.0057)\end{array}$ & $\begin{array}{l}0.022^{* * *} \\
(0.0070)\end{array}$ & $\begin{array}{l}0.008 \\
(0.0058)\end{array}$ \\
\hline \multicolumn{5}{|l|}{ Specification tests ( $p$-values) } \\
\hline Hansen test & & & 0.0004 & 0.351 \\
\hline Test for AR(1) in residuals & & & 0.0191 & 0.001 \\
\hline Test for $\operatorname{AR}(2)$ in residuals & & & 0.344 & 0.174 \\
\hline$F$ test that all $\mu_{i}=0$ & & 0.0000 & & \\
\hline$F$ test for overall significance & 0.0000 & & & \\
\hline$R^{2}$ & 0.2211 & & & \\
\hline Observations/countries & $323 / 83$ & $323 / 83$ & $240 / 83$ & $323 / 83$ \\
\hline
\end{tabular}

Notes. Standard errors are reported in the parenthesis. Hansen test is the test of the $H_{0}$ : the instruments as a group are exogenous. Hansen test statistic from two step Arellano \& Bond estimations is reported which is robust to heteroskedasticity or autocorrelation. Arellano and Bond AR(1) \& AR(2) tests in residuals are also reported. Note that to pass these tests, one has to reject the null of no $\operatorname{AR}(1)$ and fail to reject the null of no AR(2).

*** Indicates significance level of $1 \%$ against a two-sided alternative.

** Ibid., $5 \%$.

Ibid., $10 \%$.

Table 6

Unbundled institutions, human capital and growth: dynamic regressions with additional covariates

\begin{tabular}{|c|c|c|c|c|c|c|c|c|c|c|}
\hline \multirow[t]{2}{*}{ Additional covariates } & \multicolumn{10}{|c|}{ Dependent variable: annualised growth $\left(\hat{y}_{i T}\right)$} \\
\hline & $\begin{array}{l}\text { Preferred } \\
\text { specification } \\
\text { (1) }\end{array}$ & $\begin{array}{l}\text { Investment } \\
\text { share and } \\
\text { population } \\
\text { growth } \\
(2)\end{array}$ & Corruption & FDI & $\begin{array}{l}\text { Foreign } \\
\text { aid }\end{array}$ & $\begin{array}{l}\text { Real } \\
\text { exchange } \\
\text { rate } \\
\text { distortions } \\
(6)\end{array}$ & $\begin{array}{l}\text { Credit } \\
\text { to the } \\
\text { private } \\
\text { sector } \\
\text { (7) }\end{array}$ & $\begin{array}{l}\text { All } \\
\text { covariates }\end{array}$ & $\begin{array}{l}\text { With } \\
\text { EXPR }\end{array}$ & $\begin{array}{l}\text { Alcalá } \\
\text { Ciccone } \\
\text { openness } \\
(10)\end{array}$ \\
\hline Law and Order (LO) & $\begin{array}{l}0.005^{* *} \\
(0.0020)\end{array}$ & $\begin{array}{l}0.004^{* *} \\
(0.0016)\end{array}$ & $\begin{array}{l}0.006^{* * *} \\
(0.0020)\end{array}$ & $\begin{array}{l}0.004^{* *} \\
(0.0017)\end{array}$ & $\begin{array}{l}0.007^{* * *} \\
(0.0019)\end{array}$ & $\begin{array}{l}0.003^{*} \\
(0.0017)\end{array}$ & $\begin{array}{l}0.004^{* *} \\
(0.0020)\end{array}$ & $\begin{array}{l}0.002 \\
(0.0022)\end{array}$ & & $\begin{array}{l}0.007^{* *} \\
(0.0019)\end{array}$ \\
\hline Expropriation Risk (EXPR) & & & & & & & & & $\begin{array}{l}0.003^{* *} \\
(0.0014)\end{array}$ & \\
\hline $\begin{array}{l}\text { Regulation of Credit, Labour, } \\
\text { Business }(M R)\end{array}$ & $\begin{array}{l}-0.003 \\
(0.0024)\end{array}$ & $\begin{array}{l}0.002 \\
(0.0025)\end{array}$ & $\begin{array}{l}-0.003 \\
(0.0022)\end{array}$ & $\begin{array}{l}-0.003 \\
(0.0024)\end{array}$ & $\begin{array}{l}-0.002 \\
(0.0027)\end{array}$ & $\begin{array}{l}-0.0002 \\
(0.0021)\end{array}$ & $\begin{array}{l}-0.004^{*} \\
(0.0023)\end{array}$ & $\begin{array}{l}-0.001 \\
(0.0032)\end{array}$ & $\begin{array}{l}-0.005 \\
(0.0032)\end{array}$ & $\begin{array}{l}-0.002 \\
(0.0022)\end{array}$ \\
\hline Sound Money Index (SM) & $\begin{array}{l}0.003^{* * *} \\
(0.0009)\end{array}$ & $\begin{array}{l}0.0004 \\
(0.0008)\end{array}$ & $\begin{array}{l}0.002^{* * *} \\
(0.0009)\end{array}$ & $\begin{array}{l}0.002^{* * *} \\
(0.0009)\end{array}$ & $\begin{array}{l}0.002^{* *} \\
(0.0007)\end{array}$ & $\begin{array}{l}0.003^{* * *} \\
(0.0008)\end{array}$ & $\begin{array}{l}0.002^{* * *} \\
(0.0009)\end{array}$ & $\begin{array}{l}0.001 \\
(0.0011)\end{array}$ & $\begin{array}{l}0.003^{* *} \\
(0.0013)\end{array}$ & $\begin{array}{l}0.002^{* * *} \\
(0.0008)\end{array}$ \\
\hline Democracy Index (DEMOC) & $\begin{array}{l}-0.0003 \\
(0.0009)\end{array}$ & $\begin{array}{l}0.001 \\
(0.0007)\end{array}$ & $\begin{array}{l}-0.0004 \\
(0.0009)\end{array}$ & $\begin{array}{l}0.0002 \\
(0.0008)\end{array}$ & $\begin{array}{l}0.0005 \\
(0.0007)\end{array}$ & $\begin{array}{l}0.0004 \\
(0.0008)\end{array}$ & $\begin{array}{l}0.0001 \\
(0.0009)\end{array}$ & $\begin{array}{l}0.001 \\
(0.0009)\end{array}$ & $\begin{array}{l}-0.001 \\
(0.0012)\end{array}$ & $\begin{array}{l}-0.0002 \\
(0.0008)\end{array}$ \\
\hline Total years of schooling (TYS) & $\begin{array}{l}0.006^{* *} \\
(0.0026)\end{array}$ & $\begin{array}{l}0.004^{* *} \\
(0.0021)\end{array}$ & $\begin{array}{l}0.005^{* *} \\
(0.0025)\end{array}$ & $\begin{array}{l}0.006^{* *} \\
(0.0024)\end{array}$ & $\begin{array}{l}0.006^{* *} \\
(0.0026)\end{array}$ & $\begin{array}{l}0.004^{*} \\
(0.0023)\end{array}$ & $\begin{array}{l}0.005^{* *} \\
(0.0024)\end{array}$ & $\begin{array}{l}0.005^{*} \\
(0.0030)\end{array}$ & $\begin{array}{l}0.008^{* *} \\
(0.0041)\end{array}$ & $\begin{array}{l}0.007^{* * *} \\
(0.0025)\end{array}$ \\
\hline Specification tests ( $p$-values) & & & & & & & & & & \\
\hline Hansen test & 0.351 & 0.891 & 0.715 & 0.868 & 0.998 & 0.851 & 0.877 & 0.468 & 0.230 & 0.328 \\
\hline Test for AR(1) in residuals & 0.001 & 0.008 & 0.002 & 0.001 & 0.008 & 0.002 & 0.001 & 0.058 & 0.013 & 0.002 \\
\hline Test for $\mathrm{AR}(2)$ in residuals & 0.174 & 0.462 & 0.179 & 0.116 & 0.036 & 0.098 & 0.146 & 0.044 & - & 0.156 \\
\hline Observations/countries & $323 / 83$ & $319 / 82$ & $322 / 83$ & $319 / 82$ & $231 / 61$ & $300 / 77$ & $319 / 82$ & $209 / 55$ & $242 / 83$ & $323 / 83$ \\
\hline Other controls & $\begin{array}{l}\text { LTRS, } \\
y_{i T-5}\end{array}$ & $\begin{array}{l}\text { LTRS, } \\
y_{i T-5}\end{array}$ & $\begin{array}{l}\text { LTRS, } \\
y_{i T-5}\end{array}$ & $\begin{array}{l}\text { LTRS, } \\
y_{i T-5}\end{array}$ & $\begin{array}{l}\text { LTRS, } \\
y_{i T-5}\end{array}$ & $\begin{array}{l}\text { LTRS, } \\
y_{i T-5}\end{array}$ & $\begin{array}{l}\text { LTRS, } \\
y_{i T-5}\end{array}$ & $\begin{array}{l}\text { LTRS, } \\
y_{i T-5}\end{array}$ & $\begin{array}{l}\text { LTRS, } \\
y_{i T-5}\end{array}$ & $\begin{array}{l}\text { LROPEN, } \\
y_{i T-5}\end{array}$ \\
\hline
\end{tabular}

Notes. Standard errors are reported in the parenthesis. Hansen test is the test of the $H_{0}$ : the instruments as a group are exogenous. Hansen test statistic from two step Arellano \& Bond estimations is reported which is robust to heteroskedasticity or autocorrelation. Arellano and Bond AR(1) \& AR(2) tests in residuals are also reported. Note that to pass these tests, one has to reject the null of no AR(1) and fail to reject the null of no AR(2). In each regression, the standard controls are Log trade share (LTRS) and Initial income $\left(y_{i T-5}\right)$ except column 10 where Alcalá Ciccone real openness (LROPEN) is used.

*** Indicates significance level of $1 \%$ against a two-sided alternative.

** Ibid., $5 \%$.

* Ibid., 10\%. 
Table 7

Unbundled institutions, human capital and growth: dynamic regressions with alternative samples

\begin{tabular}{|c|c|c|c|c|c|c|c|}
\hline & \multicolumn{7}{|c|}{ Dependent variable: annualised growth $\left(\hat{y}_{i T}\right)$} \\
\hline & $\begin{array}{l}\text { Base } \\
\text { sample } \\
\text { (1) }\end{array}$ & $\begin{array}{l}\text { Base sample } \\
\text { without British } \\
\text { legal origin } \\
\text { countries } \\
\text { (2) }\end{array}$ & $\begin{array}{l}\text { Base sample } \\
\text { without French } \\
\text { legal origin } \\
\text { countries } \\
(3)\end{array}$ & $\begin{array}{l}\text { African } \\
\text { countries } \\
(4)\end{array}$ & $\begin{array}{l}\text { Base sample } \\
\text { without } \\
\text { Africa } \\
\text { (5) }\end{array}$ & $\begin{array}{l}\text { Base sample } \\
\text { without } \\
\text { neo-Europe } \\
\text { (6) }\end{array}$ & $\begin{array}{l}\text { Base sample } \\
\text { without oil } \\
\text { exporters } \\
\text { (7) }\end{array}$ \\
\hline Law and Order (LO) & $\begin{array}{l}0.005^{* *} \\
(0.0020)\end{array}$ & $\begin{array}{l}0.006^{* *} \\
(0.0024)\end{array}$ & $\begin{array}{l}0.002 \\
(0.0022)\end{array}$ & $\begin{array}{l}0.007^{* * *} \\
(0.0025)\end{array}$ & $\begin{array}{l}0.007^{* * *} \\
(0.0022)\end{array}$ & $\begin{array}{l}0.005^{* *} \\
(0.0020)\end{array}$ & $\begin{array}{l}0.004^{* *} \\
(0.0021)\end{array}$ \\
\hline $\begin{array}{l}\text { Regulation of Credit, Labour, } \\
\text { Business }(M R)\end{array}$ & $\begin{array}{l}-0.003 \\
(0.0024)\end{array}$ & $\begin{array}{l}-0.002 \\
(0.0022)\end{array}$ & $\begin{array}{l}-0.01^{* * *} \\
(0.0032)\end{array}$ & $\begin{array}{l}0.005 \\
(0.0036)\end{array}$ & $\begin{array}{l}-0.002 \\
(0.0023)\end{array}$ & $\begin{array}{l}-0.003 \\
(0.0026)\end{array}$ & $\begin{array}{l}-0.003 \\
(0.0024)\end{array}$ \\
\hline Sound Money Index (SM) & $\begin{array}{l}0.003^{* * *} \\
(0.0009)\end{array}$ & $\begin{array}{l}0.002^{*} \\
(0.0009)\end{array}$ & $\begin{array}{l}0.006^{* * *} \\
(0.0014)\end{array}$ & $\begin{array}{l}0.0009 \\
(0.0007)\end{array}$ & $\begin{array}{l}0.002^{* *} \\
(0.0010)\end{array}$ & $\begin{array}{l}0.003^{* *} \\
(0.0010)\end{array}$ & $\begin{array}{l}0.002^{* *} \\
(0.0010)\end{array}$ \\
\hline Democracy Index (DEMOC) & $\begin{array}{l}-0.0003 \\
(0.0009)\end{array}$ & $\begin{array}{l}-0.001 \\
(0.0008)\end{array}$ & $\begin{array}{l}-0.0004 \\
(0.0008)\end{array}$ & $\begin{array}{l}0.0005 \\
(0.0008)\end{array}$ & $\begin{array}{l}-0.0004 \\
(0.0009)\end{array}$ & $\begin{array}{l}-0.0003 \\
(0.0009)\end{array}$ & $\begin{array}{l}0.0001 \\
(0.0010)\end{array}$ \\
\hline Total years of schooling (TYS) & $\begin{array}{l}0.006^{* *} \\
(0.0026)\end{array}$ & $\begin{array}{l}0.008^{* * *} \\
(0.0022)\end{array}$ & $\begin{array}{l}0.005^{*} \\
(0.0027)\end{array}$ & $\begin{array}{l}-0.0007 \\
(0.0032)\end{array}$ & $\begin{array}{l}0.007^{* * *} \\
(0.0025)\end{array}$ & $\begin{array}{l}0.007^{* *} \\
(0.0027)\end{array}$ & $\begin{array}{l}0.006^{* *} \\
(0.0027)\end{array}$ \\
\hline Specification tests ( $p$-values) & & & & & & & \\
\hline Hansen test & 0.351 & 0.987 & 1.000 & 1.000 & 0.935 & 0.500 & 0.554 \\
\hline Test for $\mathrm{AR}(1)$ in residuals & 0.001 & 0.002 & 0.087 & 0.021 & 0.002 & 0.002 & 0.002 \\
\hline Test for $\mathrm{AR}(2)$ in residuals & 0.174 & 0.610 & 0.152 & 0.929 & 0.327 & 0.165 & 0.102 \\
\hline Observations/countries & $323 / 83$ & $210 / 54$ & $157 / 40$ & $76 / 20$ & $247 / 63$ & $311 / 80$ & $304 / 78$ \\
\hline Other controls & $\begin{array}{l}\text { LTRS, } \\
y_{i T-5}\end{array}$ & $\begin{array}{l}\text { LTRS, } \\
y_{i T-5}\end{array}$ & $\begin{array}{l}\text { LTRS, } \\
y_{i T-5}\end{array}$ & $\begin{array}{l}\text { LTRS, } \\
y_{i T-5}\end{array}$ & $\begin{array}{l}\text { LTRS, } \\
y_{i T-5}\end{array}$ & $\begin{array}{l}\text { LTRS, } \\
y_{i T-5}\end{array}$ & $\begin{array}{l}\text { LTRS, } \\
y_{i T-5}\end{array}$ \\
\hline
\end{tabular}

Notes. Standard errors are reported in the parenthesis. Hansen test is the test of the $H_{0}$ : the instruments as a group are exogenous. Hansen test statistic from two step Arellano \& Bond estimations is reported which is robust to heteroskedasticity or autocorrelation. Arellano and Bond AR(1) \& AR(2) tests in residuals are also reported. Note that to pass these tests, one has to reject the null of no AR(1) and fail to reject the null of no AR(2). In each regression, the standard controls are Log trade share (LTRS) and Initial income $\left(y_{i T-5}\right)$. Neo-Europe includes Australia, Canada, New Zealand, and United States.

*** Indicates significance level of $1 \%$ against a two-sided alternative.

** Ibid., $5 \%$.

Ibid., $10 \%$.

In column 8, we control for all covariates taken together. Only the effect of schooling survives. However, controlling for all factors drastically reduces the sample size. Also, it suffers from weak instrument problem and perhaps multicollinearity and hence is unreliable. In column 9, we replace law and order by expropriation risk-an alternative measure of market creating institutions. This measure has been used by Acemoglu et al. (2001). We find that expropriation risk, SM, and schooling are statistically significant with positive effects on growth. The impact of schooling on growth increases by 0.6 of a percentage point as a result of this change. The impact of market creating institutions proxied by expropriation risk is 0.11 percentage points less than the impact of market creating institutions proxied by law and order. The impact of SM however remains unchanged. A major drawback of using expropriation risk is that it drastically reduces the sample size. Finally, in column 10 we use Alcalá and Ciccone (2004) "log real openness" index instead of the log trade share measure. This index is a ratio of trade to PPP GDP. ${ }^{30}$ Our major findings survive even when we use this measure of trade.

In Table 7 we check the robustness of our basic finding in alternative samples. We find that the schooling, law and order, and $S M$ result survives in base sample without British legal origin countries, base sample without French legal origin countries, base sample without Africa, base sample without neo-Europe, ${ }^{31}$ and base sample without oil exporters. The magnitude of the coefficient on law and order varies from 0.004 to 0.007 which is 0.2 percent of its sample standard deviation. The coefficient on schooling varies from 0.005 to 0.008 which is 0.1 percent of its sample standard deviation. All other variables except law and order become statistically insignificant in the Africa sample. This is perhaps emphasising the importance of market creating institutions in Africa.

\section{Conclusion}

It is well documented in the existing literature that both human capital and institutions in isolation induce growth. We bring these two strands of literature together and make an attempt to isolate the partial effects of schooling and institutions in the very long run. We follow the existing literature and adopt the cross-sectional approach. However, we face

\footnotetext{
30 Alcalá and Ciccone (2004) argue that this measure performs better than the standard measure in the presence of trade-driven productivity change. However, this measure is not free from controversy. Rodrik et al. (2004) shows that the "real openness" index (Ropen) and trade volume (Open) are linked by the identity $\log$ Ropen $=\log O p e n+\log P$, where $P$ is a country's price level. Also, from the Balassa-Samuelson argument $P$ is well known to be closely associated with a country's income/productivity level. Rodrik et al. (2004) plot log Ropen - $\log$ Open on log GDP and find a positive relationship. They also find very little correlation between $\log P$ and $\log$ Open. Based on this they argue that augmenting $P$ (which has very little or no correlation to Open) into the standard trade volume measure is likely to spuriously attribute the correlation between $\log P$ and $\log G D P$ on the correlation between openness and $\log G D P$.

31 Neo-Europe includes Australia, Canada, New Zealand, and the United States.
} 
severe problems of multicollinearity in our second stage regressions. We find that the standard instruments used in the literature have strong predictive power over both the endogenous variables (institutions and schooling) and this is causing the multicollinearity problem. We then turn to dynamic panel regressions with average growth rate over five year periods as a dependent variable. Here we do not encounter the multicollinearity problems of our cross-section analysis and we are able to isolate the partial effects of institutions and human capital. Furthermore, by utilising Rodrik's (2005) four-way classification of institutions (market creating, market regulating, market stabilising, and market legitimising institutions) and identifying a proxy for each of them we are able to unbundle institutions and take it beyond property rights and contracts. We estimate the contributions of market creating, market regulating, market stabilising, and market legitimising institutions and human capital to growth. We find that strong market creating institutions and market stabilising institutions are good for growth. There exists a growth maximising level of market regulation. We believe that beyond this level it is likely that red tape increases killing the incentive for investment. Market legitimising institutions does not seem to matter. Our basic result survives across different samples and the additional covariate test.

The results contribute to a growing body of literature on institutions, human capital and growth and perhaps open up the whole debate on the interrelationship between institutions, human capital and growth. The real challenge however is to take this beyond broad cross-country country comparison and focus on the detailed workings of institutions and human capital that generates growth.

\section{Acknowledgments}

I thank the editor Daniel Berkowitz and two anonymous referees for their comments. I also thank Steve Dowrick, Andrew Leigh, Farshid Vahid, Jeffrey Williamson, seminar participants at the Australian National University, University of Melbourne, Monash University, EDGES workshop participants, and Econometric Society Australasian Meeting 2006 participants for their helpful suggestions and comments on an earlier draft of the paper. The author however remains solely responsible for the contents of this paper.

\section{Appendix A. Data appendix}

Growth $\left(\hat{y}_{i T}\right)$ : Calculated using the formula $\hat{y}_{i T} \equiv \frac{1}{5}\left(y_{i T}-y_{i T-5}\right)$ for 127 countries. Source: WDI Online, The World Bank Group.

Initial income $\left(y_{i T-5}\right)$ : Log GDP per capita PPP (constant 2000 international \$). Source: WDI Online, The World Bank Group.

Law and Order (LO): Source: ICRG, The PRS Group.

Regulation of Credit, Labour, \& Business (MR): Source: Gwartney and Lawson (2005).

Sound Money Index (SM): Source: Gwartney and Lawson (2005).

Democracy (DEMOC): Source: Polity IV.

Rule of Law (RULE): Source: Rodrik et al. (2004).

Expropriation Risk (EXPR): Source: ICRG, The PRS Group.

Executive Constraint (EXCONST): Source: Polity IV.

Repudiation of Government contracts: Source: ICRG, The PRS Group.

Legal Origin: Source: LaPorta et al. (1999).

Legal Formalism Index: Index of substantive and procedural statutory intervention in judicial cases (check case) at lower

level civil trial courts. Source: Djankov et al. (2003).

Institutions Index: Average of voice and accountability, political instability, government effectiveness, regulatory burden,

rule of law, and graft. Source: Easterly and Levine (2003).

Total years of schooling (TYS): Source: Barro and Lee (2000).

Log trade share (LTRS): Source: WDI Online, The World Bank Group.

Log Real Openness (LROPEN): Source: Alcalá and Ciccone (2004).

Log Settler Mortality (LSM): Source: Acemoglu et al. (2001).

ENGFRAC: Fraction of population speaking English. Source: Hall and Jones (1999).

EURFRAC: Fraction of population speaking European languages. Source: Hall and Jones (1999).

CONST: Constructed Openness: Source: Frankel and Romer (1999).

Latitude: Source: Hall and Jones (1999).

Landlocked: Source: Easterly and Levine (2003).

Crops/Minerals (10 variables): One-zero dummy of whether a country ever had bananas, coffee, copper, maize, millet, rice, rubber, silver, sugarcane, or wheat. Source: Easterly and Levine (2003).

Oil: One-zero dummy. One if a country is an oil producer. Source: Easterly and Levine (2003).

Investment Share: Source: PWT 6.2.

Population Growth: Source: PWT 6.2.

Corruption: Source: ICRG, The PRS Group.

FDI: Foreign direct investment as a share of GDP. Source: WDI Online, The World Bank Group.

Foreign aid: Foreign aid as a share of GDP. Source: WDI Online, The World Bank Group. 
Real exchange rate distortions: Real overvaluation. Source: WDI Online, The World Bank Group.

Credit to Private Sector: Domestic credit to private sector as a share of GDP. Source: WDI Online, The World Bank Group.

\section{Appendix B. List of countries}

\begin{tabular}{|c|c|c|c|c|c|c|c|}
\hline AGO & Angola & ETH & Ethiopia & LSO & Lesotho & SVK & Slovak Republic \\
\hline ARG & Argentina & FIN & Finland & LUX & Luxembourg & SWE & Sweden \\
\hline ATG & Antigua & FJI & Fiji & MAR & Morocco & SWZ & Swaziland \\
\hline AUS & Australia & FRA & France & MDG & Madagascar & SYC & Seychelles \\
\hline AUT & Austria & GAB & Gabon & MEX & Mexico & SYR & Syria \\
\hline BDI & Burundi & GBR & United Kingdom & MLI & Mali & TCD & Chad \\
\hline BEL & Belgium & GER & Germany & $\mathrm{MOZ}$ & Mozambique & TGO & Togo \\
\hline BEN & Benin & GHA & Ghana & MRT & Mauritania & THA & Thailand \\
\hline BFA & Burkina Faso & GIN & Guinea & MUS & Mauritius & TTO & Trinidad \&Tobago \\
\hline BGD & Bangladesh & GMB & Gambia, The & MWI & Malawi & TUN & Tunisia \\
\hline BLZ & Belize & GNB & Guinea-Bissau & MYS & Malaysia & TUR & Turkey \\
\hline BOL & Bolivia & GNQ & Equatorial Guinea & NAM & Namibia & TWN & Taiwan \\
\hline BRA & Brazil & GRC & Greece & NER & Niger & TZA & Tanzania \\
\hline $\mathrm{BRB}$ & Barbados & GRD & Grenada & NGA & Nigeria & UGA & Uganda \\
\hline BWA & Botswana & GTM & Guatemala & NIC & Nicaragua & URY & Uruguay \\
\hline CAF & Central African Republic & GUY & Guyana & NLD & Netherlands & USA & USA \\
\hline CAN & Canada & HKG & Hong Kong & NOR & Norway & VCT & St.Vincent \& Grenadines \\
\hline $\mathrm{CHE}$ & Switzerland & HND & Honduras & NPL & Nepal & VEN & Venezuela \\
\hline $\mathrm{CHL}$ & Chile & HTI & Haiti & NZL & New Zealand & ZAF & South Africa \\
\hline $\mathrm{CHN}$ & China & HUN & Hungary & PAK & Pakistan & ZAR & Congo, Dem. Rep. \\
\hline CIV & Cote d'Ivoire & IDN & Indonesia & PAN & Panama & ZMB & Zambia \\
\hline CMR & Cameroon & IND & India & PER & Peru & ZWE & Zimbabwe \\
\hline COG & Congo, Republic of & IRL & Ireland & PHL & Philippines & & \\
\hline COL & Colombia & IRN & Iran & PNG & Papua New Guinea & & \\
\hline COM & Comoros & ISL & Iceland & POL & Poland & & \\
\hline CPV & Cape Verde & ISR & Israel & PRI & Puerto Rico & & \\
\hline CRI & Costa Rica & ITA & Italy & PRT & Portugal & & \\
\hline CYP & Cyprus & JAM & Jamaica & PRY & Paraguay & & \\
\hline DMA & Dominica & JOR & Jordan & ROM & Romania & & \\
\hline DNK & Denmark & JPN & Japan & RWA & Rwanda & & \\
\hline DOM & Dominican Republic & KEN & Kenya & SEN & Senegal & & \\
\hline DZA & Algeria & KNA & St. Kitts \& Nevis & SGP & Singapore & & \\
\hline ECU & Ecuador & KOR & Korea, Republic of & SLE & Sierra Leone & & \\
\hline EGY & Egypt & LCA & St. Lucia & SLV & El Salvador & & \\
\hline ESP & Spain & LKA & Sri Lanka & STP & Sao Tome and Principe & & \\
\hline
\end{tabular}

\section{References}

Acemoglu, D., Johnson, S., 2005. Unbundling institutions. Journal of Political Economy 113 (5), 949-995.

Acemoglu, D., Johnson, S., Robinson, J., 2001. The colonial origins of comparative development: An empirical investigation. American Economic Review 91 (5), 1369-1401.

Acemoglu, D., Johnson, S., Robinson, J., 2002. Reversal of fortune: Geography and institutions in the making of the modern world income distribution. Quarterly Journal of Economics 117, 1231-1294.

Acemoglu, D., Johnson, S., Robinson, J., Thaicharoen, Y., 2003. Institutional causes, macroeconomic symptoms: Volatility, crises and growth. Journal of Monetary Economics 50, 49-123.

Acemoglu, D., Johnson, S., Robinson, J., Yared, P., 2005. From education to democracy? AEA Papers and Proceedings 95 (2), $44-49$.

Acemoglu, D., Johnson, S., Robinson, J., Yared, P., in press. Income and democracy. American Economic Review.

Albouy, D., 2008. The colonial origins of comparative development: An investigation of the settler mortality data. NBER Working Paper No. 14130, June.

Alcalá, F., Ciccone, A., 2004. Trade and productivity. Quarterly Journal of Economics 119 (2), 612-645.

Alesina, A., Dollar, D., 2000. Who gives foreign aid to whom and why? Journal of Economic Growth 5, 33-63.

Barro, R., 1995. Inflation and economic growth. NBER Working Paper No. 5326, October.

Barro, R., 1996. Democracy and growth. Journal of Economic Growth 1, 1-27.

Barro, R., Lee, J.W., 2000. International data on educational attainment: Updates and implications. Manuscript, Harvard University.

Blundell, R., Bond, S., 1998. Initial conditions and moment restrictions in dynamic panel data models. Journal of Econometrics 87, 115-143.

Caselli, F., Esquivel, G., Lefort, F., 1996. Reopening the convergence debate: A new look at cross-country growth empirics. Journal of Economic Growth 1 (3), 363-389.

Djankov, S., LaPorta, R., Lopez-de-Silanes, F., Shleifer, A., 2002. The regulation of entry. Quarterly Journal of Economics 117 (1), $1-37$.

Djankov, S., LaPorta, R., Lopez-de-Silanes, F., Shleifer, A., 2003. Courts. Quarterly Journal of Economics 118 (2), $453-517$.

Dollar, D., Kraay, A., 2003. Institutions, trade, and growth. Journal of Monetary Economics 50, 133-162.

Easterly, W., Levine, R., 2003. Tropics, germs, and crops: How endowments influence economic development. Journal of Monetary Economics 50 (1), 3-39.

Frankel, J., Romer, D., 1999. Does trade cause growth? American Economic Review 89 (3), 379-399.

Glaeser, E., LaPorta, R., Lopez-de-Silanes, F., Shleifer, A., 2004. Do institutions cause growth? Journal of Economic Growth 9, 271-303.

Gwartney, J., Lawson, R., 2005. Economic Freedom of the World: 2005 Annual Report. The Fraser Institute, Vancouver. Data retrieved from http://www. freetheworld.com.

Hall, R., Jones, C., 1999. Why do some countries produce so much more output per worker than others? Quarterly Journal of Economics 114 (1), 83-116.

Hauk Jr., W., Wacziarg, R., 2004. A Monte Carlo study of growth regressions. NBER Working Paper No. T0296, January.

Knack, S., Keefer, P., 1995. Institutions and economic performance: Cross-country tests using alternative institutional measures. Economics and Politics 7, 207-227. 
LaPorta, R., Lopez-de-Silanes, F., Shleifer, A., Vishny, R., 1999. The quality of government. Journal of Law, Economics, and Organization 15 (1), $222-279$.

Levine, R., Renelt, D., 1992. A sensitivity analysis of cross-country growth regressions. American Economic Review 82 (4), 942-963.

Levine, R., Loayza, N., Beck, T., 2000. Financial intermediation and growth: Causality and causes. Journal of Monetary Economics 46, 31-77.

Maddison, A., 2004. The World Economy: Historical Statistics. OECD, Paris.

Mauro, P., 1995. Corruption and growth. Quarterly Journal of Economics 110, 681-712.

Nickell, S., 1981. Biases in dynamic models with fixed effects. Econometrica 49 (6), 1417-1426.

Papaioannou, E., Siourounis, G., 2008. Economic and social factors driving the third wave of democratization. Journal of Comparative Economics 36 (3), $365-387$.

Persson, T., Tabellini, G., 2006. Democracy and development: The devil in the details. NBER Working Paper No. 11993.

Pigou, A., 1938. The Economics of Welfare. Macmillan and Co., London.

Przeworski, A., Alvarez, M., Cheibub, J., Limongi, F., 2000. Democracy and Development: Political Institutions and Material Well-being in the World, 19501990. Cambridge University Press, New York.

Rodrik, D., 1999. Democracies pay higher wages. Quarterly Journal of Economics 114, 707-738.

Rodrik, D., 2000. Institutions for high-quality growth: What they are and how to acquire them. Studies in Comparative International Development 35 (3), $3-31$.

Rodrik, D., 2005. Growth strategies. Handbook of Economic Growth 1 (1), 967-1014.

Rodrik, D., Subramanian, A., 2003. The primacy of institutions and what this does and does not mean. Finance and Development 40 (2), 31-34.

Rodrik, D., Subramanian, A., Trebbi, F., 2004. Institutions rule: The primacy of institutions over geography and integration in economic development. Journal of Economic Growth 9, 131-165.

Sachs, J., Warner, A., 1995. Economic reform and the process of global integration. Brookings Papers on Economic Activity 1, 1-118.

Shleifer, A., Vishny, R., 1998. The Grabbing Hand: Government Pathologies and Their Cures. Harvard University Press, Cambridge, MA.

Tavares, J., Wacziarg, R., 2001. How democracy affects growth. European Economic Review 45 (8), 1341-1379.

Wooldridge, J., 2002. Econometric Analysis of Cross Section and Panel Data. MIT Press, Cambridge. 